Original Research Report

\title{
The First Response of Family to Patient with Heart Attack in Banjarese Community South Kalimantan: A Phenomenological Study
}

\author{
M. Sobirin Mohtar ${ }^{1}$, Hamzah $^{2}$, Yuliani Budiyarti ${ }^{3}$, Solikin $^{4}$ \\ ${ }^{1}$ Emergency Nursing Department, Nursing Program, Faculty of Health, Sari Mulia \\ University. Banjarmasin, Indonesia. \\ ${ }^{2}$ Emergency Medicine Department, Medical Program, Faculty of Anesthesiology and \\ Reanimation Medicine, Airlangga University. Surabaya, Indonesia. \\ ${ }^{3}$ Maternity Nursing Department, Nursing Program, Faculty of Health, \\ Muhammadiyah University of Banjarmasin. Banjarmasin, Indonesia. \\ ${ }^{4}$ Medical Surgical Nursing Department, Nursing Program, Faculty of Health, \\ Muhammadiyah University of Banjarmasin. Banjarmasin, Indonesia.
}

\section{Article History \\ Received: \\ 23.07.2021}

Revised:

18.08.2021

Accepted:

01.09.2021

*Corresponding Author:

M. Sobirin Mohtar

Email:

sobirinmuchtar12345@gmail.com

This is an open access article, licensed under: $\mathrm{CC}-\mathrm{BY}$-SA

\begin{abstract}
Family first response in patients with heart attacks is very important in increasing patient safety. Friedman's familiy theory views that the family has a major role and function indecide the prompt and appropriate course of action. Orem's Wholly Compensatory System Theory looked at that familymust provide partial assistance when a family member is sick. Theory Cultural care Leininger looked at that family tend to maintain their culture when doing help. Indonesia, especially in Banjarmasin, has different social and cultural conditions so that the experience of making its first response will of course also be different. This study aims to explore the family experience of the first response to patients with heart attacks. This study used a qualitative method with a phenomenological study approach to 8 participants from Banjar community in South Kalimantan with purposive sampling technique. Collecting data using in-depth interviews with a tape recorder and field notes. The method of analysis uses Creswell. There are 6 themes found namely (1) The initial understanding of a family about heart attack is in the form of menyamak or angin duduk, (2) The family's first action in a patient with an attackheart in the form of cabut angin, (3) family onset in doing his first response against attacks in the form of estimated time, (4) Family delay factors in doing the first response in the form of a cause, (5) The emotional response of the family in facing a heart attack such as neutral response, anxiety and shock, and (6) meaning as a helper for family members such as pride, relief and pleasure. Nurses need to rectify the culture that is in conflict with health by changing the family mindset of their understanding of diseases, especially heart attacks.
\end{abstract}

Keywords: Emergency, Family First Response, Heart Attacks. 


\section{Introduction}

Heart disease or cardiovascular disorders is still one of the main causes of death in developed and developing countries that replace deaths due to infection [1]. In adults, cardiovascular disorders that are often encountered are coronary heart disease which causes electrical disturbances of the heart to experience cardiac arrest [2].

World Health Organitation estimates 17.5 million people died from cardiovascular disease, of which 7.4 million are estimated to be due to acute coronary syndrome and 6.7 million due to stroke [3].

Acute Coronary Syndrome (ACS) is a collection of coronary heart disease including Acute Myocardial Infarction (AMI), ST-Elevation Myocardial Infarction(STEMI), Non ST-Elevation Myocardial Infarction (NSTEMI) and Unstable Angina Pectoris (UAP) [4]. The rule out diagnosis of ACS is based on symptoms of chest pain, changes in ECG results and increases in heart enzymes, especially CK-MB and troponin T / I [5,6].

Outlines the high mortality rate heart attacks are caused by delays in getting treatment and the delay is influenced by factors of education, knowledge, beliefs, emotions, and previous experiences at the time of the attack [7]. So that delays in handling can be prevented, the first response of the family must be paid close attention to.

The theory of familiy [8] views that the family has a major role and function in decide the prompt and appropriate course of action. Orem's Wholly Compensatory System Theory [9] looked at that familymust provide partial assistance when a family member is sick. Theory Cultural care Leininger [10] view that family have a tendency to maintain the culture when doing help. The family's first response toheart attack It is very important in increasing patient safety in this case if it is not addressed it will directly affect the biological, psychological, social and spiritual aspects of the patient.

Based on the Preliminary Study obtained from the Heart Room at Ulin Hospital from January to August 2017, 447 patients with ACS medical diagnoses were found and based on the 10 most diseases in the Ulin Hospital Heart Room in June 2017, ACS with Atherosclerotic Heart Disease was ranked second after Heart Failure with an incidence rate of 24\% (as many as 22 patients) [11].

In the period of January 1, 2017 to July 31, 2017, referral data or first response data directly by families in cases of cardiovascular disease were 872 patients with ACS disease details as many as 707 cases and apart from ACS as many as 165 cases.

Interview protocol trial of 3 families of patients with heart attack At the Ulin Regional Hospital in August 2017, it was found that the three participants had the same perception, namely heart attackonly menyamak (common cold) which is not dangerous. The first response of the family was to deliver the dukun angin duduk nyamak (angin duduk), buy medicine at the shop and not immediately bring health services on the grounds that they do not understand the symptoms of attack, angin duduk cheap, just try, have become a tradition, fast and simple (lime and betel rubbed along with the reading of prayers within \pm 30 minutes). Family onset is quite long (more than 1 hour). The response of the family when the attack was shocked (excited) and sad, but when convicted was unexpected, resigned and natural. In addition, data were also obtained from families with low education (SR, SD and not going to school), low economic status, wrong beliefs (tradition of angin duduk out the nyamak), and access to health services quite far ( $\pm 10 \mathrm{~km}, \pm 15 \mathrm{~km}$ and $\pm 20 \mathrm{~km}$ from the house) which is the cause of help.

Based on the above phenomena, there are various kinds of family actions in giving the first response to patients who experience it heart attack. Indonesia, especially the people in Banjarmasin, South Kalimantan, have social and cultural conditions that are different from conditions in other countries so that the experiences experienced by families, especially in giving their first response (prehospital), of course, may also be different. This study has explored this phenomenon using a qualitative phenomenological approach, the phenomenological approach is an approach that can explore family experiences in giving their first response to patients withheart attack in depth.

\section{Methods}

This research uses a qualitative study with a phenomenological approach. Phenomenology provides a deep understanding of phenomena as experienced by some individuals. To explore a deep and naturalistic experiencehis first response in patients with heart attack. The population in this study is the nuclear family who has experience in doinghis first responsein family members who have had a heart attack with diagnostic evidence from the medical records of the cardiac poly room, the heart 
inpatient room and the ICCU room of the Ulin Hospital as many as 447 families. Participants in this study amounted to 8 families who have experience in doingfirst response in family members with heart attacks (ACS). Data were collected using in-depth interviews with Tape Recorder and Field Notes. The method of analysis uses Creswell [12].

\section{Thematic Analysis Results}

The theme analysis was obtained from the results of interviews in this study on the first response family in the patient heart attack. Generates 6 main themes found like:

1. The initial understanding of the family against heart attacks

2. Family first action in a patient with a heart attack

3. Family onset in givinghis first responseagainst a heart attack

4. Factors of delay in the family in providinghis first responseduring a heart attack,

5. The emotional response of the family in the first time they face a heart attack

6. Meaning as a helper for family members.

Researchers will recite these themes per sub-theme to gain an understanding of how the two themes are formed based on the experiences of the participants.

\subsection{Early family understanding of heart attacks (Theme 1)}

Common illness (sub-theme 1.1)

Participants perceived that a heart attack was an ordinary disease, namely a menyamak disease such as a cold. A cold is considered to be just someone who is not feeling well. The six participants expressed the usual menyamak disease as follows:

"Yes .. amun jar (according to) we menyamak there was angin duduk in the bosom, well ... like that pressed the chest ... Menyamak ..." (P1)

"The term catches a cold ... the jar urang (according to the people) the banjar is subject to washing (menyamak) ..." (P3)

"We think that we are afraid of menyamak that becomes crowded, if it is automatic, ordinary thoughts are like us, yes ..." (P4).

"Menyamak!!! If the Javanese language is angin duduk, sitting means most of the wind ... the wind is in the chest ... the sea is evil, the term is bad wind or good wind, the language of the banjar is menyamak... "(P8).

Apart from being perceived as a menyamak disease, heart disease is also perceived as a common stomach ulcer. Heartburn is usually considered just a person who has pain in the stomach or stomach, as stated by one participant below: "The possibility of a sick stomach ..." (P5).

\subsection{Family First Action in a patient with heart attack (Theme 2)}

Alternative Medicine (sub-theme 2.1)

The first action taken by the participants was alternative medicine such as blowing the wind or angin duduk by means of massage, the following is the expression:

"Sorted kaytunah (while practicing) ..." (P5)

Other participants also did it by means of being rubbed (rubbed), the following was the expression:

"Dikasai'ai (rubbed) !!! (answers aloud along with hand movements) ... "(P2)

"Ditamba'i (treated) removed the wind in the traditional way (in kasai)" (P8)

In contrast to this one participant in Alternative Medicine using Pain Relief Cream, here is the phrase:

"At the counterpain, okay ..." (P7). 
How Alternative Medicine Works (sub-theme 2.2)

Various sequences of treatment actions taken and experienced by the following participants in helping their family members when experiencing an attack, here's how it works:

"Massaged (massaged) the chest into the wooden hands of pang (like that) pinan (apparently) yesterday ..." (P1)

"The soap was recited by a prayer, strengthened (rubbed) while blowing the opponent's prayers tadih, when the betel leaf came home, it was only allowed to stand for $\pm 2-3$ minutes ... (participants seemed to practice one by one)" (P2)

"Betel leaf or jackfruit kulanda (soursop leaf) made with which is used for chewing (traditional tooth cleaner) dikasaikan di awak (smeared on the sick) red the holy quran ...”

\section{Duration of Action Alternative Medicine (sub-theme 2.3)}

Estimates of the length of time required in alternative medicine range from \pm 3 to 15 minutes. Here's the expression:

"Well, it takes about 15 consecutive minutes" (P1)

"At most 10 minutes ..." (P2)

"Kada old jua (not too long) massaged .." (P3)

"5 minutes gin tuntung ..." (P4)

"5 minutes until gin kada ..." (P5)

"Just as usual .." (P6)

"Asumat (briefly) wrote ... 3 minutes or 5 minutes it feels ..." (P7)

"At most half an hour. ..... Older kada also (not too long)" (P8)

\section{Benefits of Alternative Medicine (sub-theme 2.4)}

The first action taken by the participants for them is believed to be able to get rid of the disease in the body (cure pain):

"If according to Sidin ampih (he is cured) the pain .." (P3)

"I ask for a sense of comfort, a sense of looseness (relief) kaytunah (like that) .." (P5)

"Throwing the wind ... yes throwing the wind (relieving the pain) the wind sits tadih, if the term banjar is menyamak ..." (P8).

\section{Reasons for Choosing Alternative Medicine (sub-theme 2.5)}

Various reasons why the participants chose alternative medicine over health services. Here's the expression:

"We thought it was menyamak ..." (P1)

"Sidinnya (he) considers normal illness, catches sidin jar colds .." (P3)

Participants reasoned that they chose alternative medicine because in addition to respecting the beliefs that exist in their families, they also follow the opinions of older people, as follows:

"Listen to the tuha (old) lo ngarannya (name) brother, bro, the tuha huh ..." (P1)

Participants choose alternative medicine for reasons other than distance, the following expressions:

"Massager (masseuse) tuh pang next to the container (where) his brother is just comfortable ..." (P1).

One participant does not have a means of transportation to get to health services, the following reasons:

"The obstacles in the means of transportation are not there ..." (P4)

The costs incurred for alternative medicine are very cheap and affordable, here are the reasons: 
"The cost of kada is too much, it's too late ..." (P1)

In action it is easy and the reaction is quick to heal, here are the reasons:

"Wiped it (wiped it) or angin duduk it out (just) lost it .." (P2)

Participants reasoned that they chose alternative medicine because they thought that the drugs that had been obtained from health services were not suitable, the following reasons:

"I was given vitamins ... lowering the pressure ... I was tired ... so I felt the pain was very strong (not cured) suadahay .. looking for someone who can strengthen (rub) or can angin duduk the wind tadih (looks angry and disappointed)... "(P2)

Participants were disappointed with health services, because when a family member needed help, the health service did not serve him immediately, the following was the statement:

"If we ask for a referral through a beucap which determines our referral is not pian !!! (seemed to say it out loud and held back feelings of annoyance, anger and disappointment) ..." $(P 2)$

The unwillingness of participant family members to seek treatment is an obstacle for the family, here are the reasons:

"Because Sidin Kada wants it (he doesn't want it), if we are explosive (really want) we have to bring pain ..." (P3)

One participant reasoned that if his family members were taken to the hospital, they felt confused about where to start, the following reasons:

"The father is confused about where to take him first, afraid that someone will not be able to take care of mas-ay ..." (P4)

Participants argued that self-medication is a habit in each illness, here are the reasons:

"The habit until now, if you are sore, use a powerful counterpain (get well) ..." (P6)

\subsection{Onset Family in Giving His First Response Against Heart Attack (Theme 3)}

Estimated Time (sub-theme 3.1)

Onset the emergence of attacks of first responseWhat the participants did was quite different, some were seconds, minutes and even hours. Here are the differences:

"Just go ahead ..." (P2)

"Just go ahead ..." (P5)

"Coming more than 15 minutes ..." (P3)

"Something like that (almost an hour) ..." (P4)

"15 minutes it's already anu pang ... it's been trodden ..." (P7)

"It's almost 30 minutes..." (P1)

"There is 1 hour ..." (P6)

"Old Kada is also (not too long) the distance, so it hurts immediately calls the family ..." (P8)

Onset the first response of the familyuntil arriving at the hospital is quite different, some are in minutes or even hours. Here are the differences:

"About 30 minutes from home to the hospital, it feels like ..." (P1)

"15 minutes ..." (P6) 
"I only waited for the ferry for 1 hour, arrived at the TPT for 2 hours, around 1 hour there ... then I was referred to here at Ulin Hospital (> 4 hours) ..." P2)

"If the distance at home is 50 Kilo ( \pm 2 hours) .." (P3)

"At least half an hour until ..." (P4)

"1 hour there ..." (P5)

"That's $1 / 2$ hour long ..." (P7)

"At most 1 minute, 2 minutes at the most ... beyond banar (very long) ..." (P8)

\subsection{Factors of Family Delay in Giving First Response During a Heart Attack (Theme 4) Causes of Delayed Family Assistance (sub-theme 4.1)}

The following participants revealed that what makes delays in help occurs because of the patient's unwillingness and unwillingness to communicate, this is because the patient's coping is ineffective in dealing with his illness. Here's the expression:

"Sidin hard kada wants (doesn't want) to be taken to the hospital ..." (P3)

This delay in participants was caused by the distance and time traveled from home to health services, as follows:

"If you cross it for about 20 minutes but waiting for it, this is the old one (old), there are those who 1 hour meahadangi inya ja (waiting for him) ... (looks annoyed)" (P2)

The following participants whose delays were due to the length of time they spent on alternative medicine:

Oversight (too long) also (also) sorted (massaged) until it turns blue (sitting with his arms crossed and looking panicked) ... "(P1)

The following is the participant's expression regarding the knowledge that is a factor of delay:

"Considering that it is normal to have a cold, catch a cold from ulcer, we don't know the disease ..." (P3)

"Do not understand what the symptoms of a heart attack are, so that they deliver traditional healers to menyamak ..." (P8)

\subsection{Family's emotional response to a heart attack for the first time (Theme 5)}

Family Response at First Attack (sub-theme 5.1)

This participant describes the psychological response of the family when a family member first experiences a heart attack with a mediocre response, as expressed below:

"If the feeling is because you menyamak, you are 'normal', it's just normal ... (participant response looks flat)" (P1)

Other participants also revealed that the response of the family when a family member experiences an attack is anxiety, as stated below:

"Panic, bro, if I panic alone, so I don't sleep too, suggesting that the father can't sleep, I'm afraid ... panic, confused about who wants to help (looks worried) ... (P4)

Participants revealed that the response of the family when a family member has a heart attack is feeling shocked. Here's the expression:

"Panic saw inya (her) chest pain (looked shocked and anxious) ..." (P5) 


\subsection{The Meaning of Being a Helper for Family Members (Theme 6) Perceived Things (sub-theme 6.1)}

The feeling expressed was like feeling proud when one of the participants, namely his own son, had helped his father (a member of his family) even though it was not destiny to say otherwise (not helped):

"Amun proud there is a pang ... because I have helped my brother as much as possible ... (participants seem to smile)" (P1)

A child and his min-in-law feel relieved when they have taken their parents or in-laws to a better hospital even though they know it is far and away risky:

"I feel relieved, my heart ... I have been helped ... it means that someone is already handling it, if someone is in the hospital, it has been carried directly, by the nurse or nurse ... (looks happy and there is no burden" (P7)

This participant is very happy because she is grateful that her husband and one parent have survived until now. Here are the expressions:

"Yes, I am grateful (happy) that I (can) be helped, so that the lakas will be effective (get well soon), in order to reduce the pain at the most (at least), but (if it is cured) maybe it will reduce God willing ... looks very happy) "(P5)

\section{Discussion}

\subsection{Early Family Understanding of Heart Attacks}

The first findings in this study are early family understanding of heart attacks with the sub-theme of common disease. Each participant's unique and varied understanding of the perception of a heart attack in the perception of banjar culture with the term menyamak Disease and Javanese culture with the term angin duduk Disease.

In line statement that the term menyamak or angin duduk itself is still ambiguous or ambiguous, where the term colds itself does not exist in medical terms or is also called the term ethnomedicin disease [13].

These findings are confirmed in the study stated that a heart attack is an event of obstructing coronary artery blood flow which causes the heart muscle to be deprived of oxygen until an infarction occurs, and heart attack is the most urgent emergency condition that requires precise and prompt diagnosis and treatment to save the heart from more severe damage [14].

The next finding in this theme is that heart disease is also perceived as a disease. Heart disease is also perceived as a disease Gastric pains. Common heartburnconsidered only someone who has pain in the gut or pain in the stomach. Describes a typical complaint in ACS is retrosternal chest pain (behind the sternum), such as squeezing, pressing, stabbing, heat or being crushed weight. Pain may be accompanied by feelings of nausea, vomiting, shortness of breath, dizziness, cold sweats, palpitations or syncope and the patient often appears frightened [15].

From the two categories above, it is explained that participants in understanding the disease perceive their family members to the wrong disease without knowing later it will affect the next follow-up and the family must do one of the five duties and functions of the family by making and giving quick and correct decisions to members who have a heart attack, regarding the culture of nurse participants must also straighten out about culture that is contrary to health and change set the family will understand the disease, especially heart attacks.

This is in line theory that nurses should do Cultural Care Repatterning or Restructuring Namely the principle of reconstructing or changing the design to help improve health conditions and family life patterns for the better [16]. The restructuring process includes assisting, supporting, facilitating, or enabling professional action and decisions that help families restructure, change, or greatly modify their lifestyle for new, different and profitable health care patterns, while respecting cultural values and beliefs family. 
In line with the theory of Friedman health problems in the family are interrelated so that if one family member has a health problem it will affect other family members, as well as the family remains and always plays a role as a decision maker in maintaining the health of its members [8].

In addition to providing quick and appropriate decisions when family members experience an emergency, in this case experiencing an attack, the family must provide partial assistance in this case helping their family members by finding and contacting emergency services.

Orem (2001) emphasizes in his system theory, namely the Wholly Compensatory System (partial support system) that the family is a system in providing partial self-care and is aimed at patients who require minimal response, such as patients with heart attacks, in this case family members who play a role in it. to be able to carry out the duties and functions of his family, one of which is to make the right decisions on the health problems of his family members to seek emergency health service assistance.

After the family did Wholly Compensatory System (partial support system) to family members who experience an attack, in this case they have already arrived at the hospital so the next action is the nurse's responsibility in providing The full support system (Wholly Compensatory System).

In line with Orem's theory asserts in his system theory, namely the Wholly Compensatory System which is a nursing action by providing full assistance to patients with heart attacks due to the patient's inability to fulfill independent care measures that require assistance in movement, control and ambulation as well as movement manipulation [9]. The provision of assistance to this system can be done to people who are unable to carry out activities on purpose such as in comatose patients who are conscious but in an emergency condition and may still be able to make observations such as heart attacks who are unable to take care of themselves, make judgments and decisions in self. care, in this case, medical personnel or nurses who play a full role in it.

\subsection{Family First Action in a patient with heart attack}

The findings obtained indicate that The first action taken by participants in carrying out assistance to their experienced family members heart attacknamely with alternative treatments through massage, rubbing and the use of pain relieving creams. Alternative treatment in the form of massage or massage is very useful in treating pain but it is different if the pain leads to emergency diseases such as chest pain due to heart disease, regarding this, the family should play its duties and functions as a family that the family must be able to prevent and fix existing problems. in his group.

In line with theory Friedman that families must carry out health care or maintenance can be seen from the family health duties in this case recognizing family health problems, making decisions for appropriate health actions, using existing health facilities in the community, maintaining a healthy home atmosphere and provide care to family members who are sick [8].

Maintaining the culture is done if the culture of the family and the patient does not conflict with health, in this case if the family member's experience it heart attackIf an alternative treatment is taken, it is contradictory because the patient is in a serious condition, so it must be done quickly and precisely. Nursing planning and implementation are given in accordance with the values that are relevant to those of the family, so that the family can improve or maintain the health status of their family members.

This is in line with Leininger's theory in Gonzalo, that nurses must do Cultural Care Preservation or Maintenancenamely the principle of helping, facilitating, or paying attention to cultural phenomena in order to help individuals determine the level of health and the desired lifestyle. This principle also enables actions and decisions that help families and clients of a particular culture to maintain or preserve the values of relevant care, so that they can improve, recover from illness, or face disability and / or death [17].

Nurses help families and clients to be able to choose and determine other cultures that are more supportive of improving health, for example, moderate clientsheart attack, then the nurse must negotiate and bargain with the family in a way that the nurse maintains his culture such as alternative medicine is just a side action if necessary, this means that alternative action may be taken when a family member recovers from his attack and the rest when in this emergency situation entrusting health professionals such as medical treatment measures (pain assessment, ECG examination and cardiac enzyme lab tests).

This is in line with Leininger's theory in Gonzalo that nurses must do Cultural Care Accommodation or Negotiation Namely the principle of negotiation, support, help facilitate, or pay 
attention to cultural phenomena that reflect ways of adapting, enabling creative professional action and decisions to help families of the designated culture to negotiate or consider the health conditions and lifestyle of their family members [17].

Cultural restructuring is carried out when the culture that is owned is detrimental to health status. The nurse tries to restructure the lifestyle of family members who usually smoke to not smoke. The pattern of life plans chosen is usually the one that is more profitable and in accordance with the beliefs held, because with one of the supporting factors it emergesheart attack is an unfavorable lifestyle such as cigarettes and so on.

This is in line with Leininger's theory in Gonzalo that nurses must do Cultural Care Repatterning or RestructuringNamely the principle of reconstructing or changing the design to help improve health conditions and family life patterns for the better. The restructuring process includes assisting, supporting, facilitating, or enabling professional action and decisions that help families restructure, change, or greatly modify their lifestyle for new, different and profitable health care patterns, while respecting cultural values and beliefs family [17].

Next nurses must adapt and adapt to the needs of the culture that the patient's family believes in and the nurse studies it through nursing care with the Sunrise Model approach. In line with Leininger's theory in Pratiwi, that the nurse has to do Culture Congruent / Nursing Care Namely, an awareness to adjust cultural values or beliefs and ways of life of individuals or groups or institutions in an effort to provide useful nursing care [18].

Further findings were obtained bThere are various ways of working alternative medicine actions that are carried out and experienced by participants in helping their family members when having a heart attack whose basic ingredients in how they work cannot be separated from the use of surrounding plants such as betel leaf and lime through massage or basting techniques. The Banjar tribe in South Kalimantan to date still maintains the tradition of utilizing the surrounding plants for treatment or health care, although in fact the reach of health services such as Puskesmas is increasingly reaching the interior, but in reality health services are not evenly distributed, so the methods of treatment traditional still have a place in the community.

In line with research reveals some of the workings of alternative medicine by utilizing whiting as a chest pain treatment. How it works The water is squeezed lime, add a little whiting, salt and eucalyptus oil, the water is rubbed on the chest [19].

The next finding is the duration of alternative actions taken by the participants themselves and others, ranging from \pm 3 to 15 minutes. Alternative medicine methods that people use in alternative medicine are sometimes very illogical, such as the length of action and the use of animal media for disease transfer, the use of supernatural powers.

Stated that in 2009 in the Jombang area the treatment was carried out by a 10 year old boy named Muhammad Ponari. The method of treatment is very simple and quite short, namely by dipping the stone in Ponari's hand into the water then drinking it and 30 minutes after drinking it, the pain will immediately heal [20].

Alternative medicine, both massage and basting techniques, uses the basic ingredient of betel as a basic ingredient which is believed to contain chemical compounds which apart from being the most antibiotics as well as aromatherapy and body warmers. In line with research, betel leaves also contain essential oils (a distinctive aromatic giver) [21]. In traditional medicine, especially in treating pain, betel leaf is known as an aromatic substance that can warm the body so that from the warmth it can inhibit pain and prevent the pain from spreading. Stated in the argument he delivered at the annual meeting of "The American Psychiatric Association", that maybe one day we doctors will write down do'a on prescription paper in addition to prescription drugs for patients [22]. Because from studies that have been conducted by experts, it turns out that $72 \%$ stated that religious commitment (prayer) shows a positive effect on patients.

There were various reasons why participants should choose alternative medicine instead of health services, including ignorance of the disease, following opinions, distance, transportation, costs, getting well soon, treatment incompatibility, disappointment, unwillingness, confusion and habits.

Sunrise model Leiningers in Pratiwi, states that this is included in the Education Factors component [18]. The higher the client's education, the more his belief must be supported by rational scientific evidence and can learn to adapt to a culture that is in accordance with his health conditions. 
Sunrise model Leiningers in Pratiwi, states that this is included in the components of Social Factors and Kinship Bonds (Kindship and Social Factors) where the social and familial factors need to be studied by nurses [18].

According to one of the factors of the cultural dimension in the schema sunrise model Leiningers in Pratiwi, states that this is included in the Economic Factors component where the client is hospitalized using material resources to pay for his illness so that he can get well soon [18]. Sunrise model Leiningers in Pratiwi, states that this is included in the Technological Factors component where health technology is a means that allows humans to choose or get offers to solve problems in health services [18]. Sunrise model Leiningers in Pratiwi, states that this is included in the Cultural Values and Lifeways component (Factors of Cultural Values and Lifestyle) where values are abstract conceptions in humans, about what is considered good and what is considered bad [18].

\subsection{Onset Family In Giving His First Response Against Heart Attack}

The findings the time taken by the participants duringfirst responsequite different there are seconds, minutes, hours. Speed of treatment was assessed from the Time window or Golden period between patients arriving at the hospital, target for starting fibrinolytic therapy (door-to-needle time) $=30$ minutes, whereas Primary PCI (door-to-ballon) time) $=90$ minutes [23]. Ginzburg et al, (2012) Relief period divided by 2 time intervals: (not $>1$ hour), the current time span from onset toheart attack is one of the main factors determining treatment [24].

\subsection{Factors of family delay in giving first response during a heart attack}

The findings Participants in doing his first responsethere are many things that make it late, such as uncooperative, distance traveled, the length of time for alternative medicine and the family's ignorance of the disease, leading to disability and even death. Friedman (2010) The duty of the family towards family members is the main effort of the family to find help that is appropriate to the family situation. The high problem of patient safety is due to low knowledge of signs and symptomsheart attackand doubts between asking for medical help or handling it yourself [25, 26].

\subsection{Family's emotional response to a heart attack for the first time}

Did get a family response when a family member first experiences an attack with a normal response, anxiety \& surprise. If what arises to something is a feeling of pleasure (positive) and displeasing (negative), if there is no feeling of nothing, it means neutral [27]. As an adaptive system, humans are always faced with various complex problems (anxiety) so that they are required to adapt to various incoming stimuli and also explain that everyone always uses coping, both $+/-$ to be able to adapt [28]. That a good coping mechanism can reduce the level of individual or group family anxiety [29]. This reaction opens up the possibility of more information about the unexpected event, making it easier to understand what actually happened and develop the best plan of action [30].

\subsection{The meaning of being a helper for family members}

Participants as a family have their own meaning after helping family members who are experiencing attacks, such as pride, relief, joy. When a person hears that he is considered "great" then he will have pride in himself and then will maintain his "greatness". It should be noted, however, that a story about "greatness" is not necessarily a story from the positive side of a person. Someone who often hears him told from the side of his kindness, will be proud of his kindness [31]. Feels relieved by individuals because conditions caused by stress have disappeared or changed for the better [32]. Gratitude is a feeling of awe, gratitude, and appreciation for life [33].

\section{Conclusion}

The nurse needs to straighten out the culture that is in conflict with health by changing the set of the family's understanding of disease, especially heart attacks.

\section{References}

[1] Kemenkes RI, "Penyakit jantung penyebab kematian tertinggi, kemenkes ingatkan cerdik," July 2017. [Online]. Available: https://www.kemkes.go.id/article/print/17073100005.htm. [Accessed: May. 2, 2021]. 
[2] Mohta, "Principles of Patient Centered Care (PCC) in Emergency Nursing Care Cardiovascular Activity Case," Caring Nursing Journal. vol. 5, no. 1, 2015 [Online]. Available:https://journal.umbjm.ac.id/index.php/caring-nursing/article/view/634 [Accessed: May. 2, 2021].

[3] World Health Organitation, "Cardiovascular disease mortality," 2015. [Online]. Availbale: https://www.who.int/health-topics/cardiovascular-diseases\#tab=tab_. [Accessed: May. 2, 2021].

[4] Gayatri, "Predictors of In-Hospital Mortality Patients with ST Elevation Myocardial Infarction (STEMI) in dr. Dradjat Prawiranegara Serang, Indonesia," CDK-238, vol. 43, no. 3, 2016.

[5] C. P. Cannon, and E. Braunwald, Unstable Angina. In Braunwald: Heart Disease; A Textbook Of cardiovascular Medicine, 6th ed. USA: WB Saunders Company, 2001.

[6] Susilo, "The Relationship Area of Myocardial Infarction (Based on Selvester Score) with Chest Pain Response in Acute Coronary Syndrome (ACS) patients in RSD Dr. Soebandi Jember," Journal of Nursing, vol. 1, no. 2, 2013.

[7] Herning, "Women's experiences and Behavior at Onset of Symptoms of ST Segment Elevation Acute Myocardial Infarction," European Journal of Cardiovascular Nursing, vol. 10, pp. 241247, 2011.

[8] M. M. Friedman, Family Nursing: Research Theory, Practice. $5^{\text {th }}$ edition. New Jersey: Prentice Hall, 2010.

[9] D. E. Orem, Nursing: Concepts of Practice (6th Ed.). St. Louis: Mosby, 2001.

[10] M. Leininger, Transcultural Nursing: Concept. Theorist. Research \& Practice. 3rd Edition. USA: McGraw-Hill, 2001.

[11] Hospital Ulin Banjarmasin, Archives of Medical Records of Cardiac Room Inpatient Hospital Ulin Banjarmasin. Banjarmasin: Bagian Arsip Hospital Ulin Banjarmasin, 2017.

[11] J. W. Creswell, Qualitative, Quantitative, and Mixed Methodes. Third Edition. California: SAGE Publication, Inc, 2014.

[12] Manggia, "Often Called Heart Disease the Wind Sits," January 2018. [Online]. Available: https://ikapesta.com/wpcontent/uploads/.../Mengenal-Efek-Spesial-dalam-Party.pdf. [Accessed: April. 2, 2021].

[13] Kurniawan, "Patients Experience Heart Attacks the first time he was treated in the CICU Room," Journal Medicine, vol. 3, no. 2, 2015.

[14] Sunaryo, and lestari, "Effect of Benson Relaxation on Scale Decrease Left Chest Pain in Acute Myocardial Infarc. Patients at RS. Dr Moewardi Surakarta," Integrated Journal of Health Sciences, vol. 4, no. 2, pp. 82-196, 2015.

[15] M. M. Leininger, (2011). Transcultural Nursing: Concept. Theorist. Research \& Practice. 3rd Edition. USA: McGraw-Hill, 2011.

[16] Gonzalo, and A. G. Madeleine, "M. Leininger-Theoretical Fondation of Nursing," January 2018. [Online]. Available: http://nursingtheories.weebly.com/madeleine-m-leininger.html [Accessed: April. 2, 2021].

[17] Pratiwi, Textbook of Transcultural Nursing. Yogyakarta: Gosyen Publishing, 2011.

[18] Widyawati, "Empowering the urban medicinal garden through descriptions and benefits of medicinal plants," Pros Seminar Masyarakat Biodiv Indonesia, vol. 1, no. 8, pp. 1890-1895, 2015.

[19] I. Ilmie, "The Ponari phenomenonin Medical and Sociological Review," February 2009. [Online]. Available: http://health.kompas.com/read/2009/02/23/18095223/Phenomena Ponari. [Accessed: April. 2, 2021].

[20] Mulyono, Efficacy and Benefits of betel leaf: Effective medicine from time to time. Jakarta: Agro Media Pustaka, 2005.

[21] Z. Ali, Religion, Health and Nursing. Jakarta: CV Trans Info Media, 2010.

[22] Widimsky, "Efforts to empower urban living pharmacies through descriptions and benefits of medicinal plants," European Heart Journal, vol. 31, pp. 943-957, 2010.

[23] Ginzburg, "The Analysis of Factors Influencing the Terms of Hospital Admission in Patients with Acute Coronary Syndrome (Accordingto the lis study data - lyubertsy study on mortality rate in patients after acute myocardial infarction)," РаииональнаяФармакотерапия в Кардиологии, vol. 8, по.2, 2012.

[24] T. Kelly, and L. Howie, "Working with stories in nursing research: procedures used in narrative analysis," International Journal OfMentally Health Nursing, vol. 16, pp. 136-144, 2010. 
M. Sobirin Mohtar, Hamzah, Yuliani Budiyarti, Solikin.

The First Response of Family to Patient with Heart Attack in Banjarese Community South Kalimantan: A Phenomenological Study.

International Journal of Clinical Inventions and Medical Sciences, vol. 3, no. 2, pp. 67-77, September 2021. DOI: 10.36079/lamintang.ijcims-0302.248

[25] R. Peter, and Cathrine, Cardiovascular Disease: Fight It With The Blood Type Diet. Jakarta: BIP, 2006.

[26] Sarwono, Social Psychology. Jakarta: Salemba Humanika, 2009.

[27] S.C Roys, the Roy Adaptation Model. New Jersey: Pearson Education, 2009.

[28] Taluta, "Relationship between Anxiety Levels and Coping Mechanisms in Sufferers Type Ii Diabetes Mellitus at the Internal Medicine Polyclinic of the Tobelo Regional General Hospital, North Halmahera Regency," Nursing Journal (e-Kp), vol. 2, no. 1. 2014.

[29] Goleman, Emotional Intelligence Emotional Intelligence Why EL is more important Than IQ. Jakarta: PT. Gramedia Pustaka Utama, 2007.

[30] G.A. Kimble, N. Garmezy, and E. Zigler, Principles of General Psychology. 5th Ed. New York: John Wiley \& Sons, Inc, 2001.

[31] Lazarus, RS Emotion and Adaptation. New York: Oxford University Press, 2001.

[32] C. R. Snyder and S. J. Lopez, Handbook of positive psychology. New York: Oxford University Press, 2005. 